\title{
ANDRÁs SAJó* \\ The Impacts of EU Accession on Post-communist Constitutionalism
}

\begin{abstract}
One of the persistent fears regarding the accession countries envisions that these countries will not catch up with the prevailing practices of constitutionalism and the rule of law that allegedly constitute the common tradition of Europe.

It is believed, and in many regards rightly so, that accession to the Union will push Eastern Europe towards the values and institutional settings of modernity. Given the process and political consequences of the accession, as well as for other, historical and cultural reasons, the short term modernization effects of the membership might be limited, even counterproductive. This paper discusses the impact of the current "Europeanization" on the public understanding and institutional structures of constitutional democracy in the new member states. Further, it evaluates the foreseeable impacts of the emerging European Constitution on the constitutional structures (the new checks and balances) in the new member states, except the human rights aspects of constitutionalism.
\end{abstract}

Keywords: accession constitutionalism European Union referendum sovereignty

\section{Introduction}

One of the persistent fears in the European Union is that the accession countries will be unable to catch up with the prevailing practices of constitutionalism and the rule of law that supposedly ground the common tradition of Europe. This fear is rationalized when considering that unbridled nationalism necessarily impacts upon territorial stability. There are other concerns regarding the weakness of democratic tradition especially after the years of totalitarian rule. It is believed that the institutional systems in place for enforcing the rule of law ${ }^{1}$

* Member of the Hungarian Academy of Sciences, Professor of Law, Institute for Legal Studies of the Hungarian Academy of Sciences, H-1014 Budapest, Országház u. 30.; Professor, Central European University, Budapest, Legal Studies.

E-mail: sajoand@ceu.hu

${ }^{1}$ In fact, both new and old member states confront with some difficulty the aggressive enforcement of bureaucratic (excessively bounded) rationalism that relies on Union supremacy to the detriment of nation-state level constitutionalism. For the old member states see, e.g., the Alcan decision. C 24/95, Alcan II, [1997] ECR I-1591. [German rule of law concept disregarded by the ECJ]. 
merely exist in a formal sense rather than in terms of self-sustaining value commitments. The scope of this chapter does not allow for an analysis into the truth of such assumptions. It is undeniable that extremist nationalism is not absent in the rhetoric, and sometimes actual policies, of Eastern European political elites who in turn find popular endorsement for their nationalistic campaigns. ${ }^{2}$ These nationalistic sentiments will be echoed once the population of new member states will be confronted with negative experiences as a result of them being unable to successfully articulate their special interests in a great "empire"; unfavorable comparisons of "Brussels as the new imperial power" with the "yoke of the Soviet empire" has already been made in many former communist countries.

One of the striking features of East European nationalism is that it is embedded in a value system that is (at best) indifferent to modernity as it grounds itself in past (ascribed and mystical) national glory. This belief does not generate much interest in the ethics of modernity as put forward in the rule of law (rational accountability for one's acts, transparency, predictability through formalism, etc). Modernists (modernizers) argue that accession will change attitudes toward modernization among large segments of the population. However, given the process of accession and the way the new Union is shaped, firm, popular commitment to an efficient democracy as well as the belief in popular self-government, such an efficient responsive and responsible modern institutional system has limited opportunities to prevail beyond the institutional façade. Citizens of the new member states might become Zwangsdemokraten (forced democrats). ${ }^{3}$ This is problematic because so long as the new European constitutional identity remains an unfinished and uncertain project (an imposed mask) there will be only limited offering of a modernizing identity. It is also true that the Eastern European political elite seems to have a very instrumentalist disregard ${ }^{4}$ for the rule of law even though formal legalism

2 The Summer, 2003 Gallup poll indicates that although many Hungarians and Estonians identify themselves as citizens of the nation-state only (39 per cent) this is not particularly high compared to Great Britain (64 per cent). However, there was no Hungarian who would have identified himself/herself as "European only". Hungarian identity correlates with age but not with party affiliation.

3 The term was used by a German journalist in regard to the late Bavarian Prime Minister Franz-Joseph Strauss. Of course, given certain historical circumstances the progress to genuine democracy might lead through imposed democracy.

4 It is quite telling that the Hungarian Government's chief delegate to the European Convention who joined overwhelming majority of the delegates signing a document proposing that the new Constitution should be adopted by national referenda, stated in Hungary that he does not find appropriate to call a referendum; his signature was added as 
is at least accepted. (Even Meciar accepted unfavorable decisions of the Slovak Constitutional Court.)

Instrumentalism and the hidden contempt of the rule of law and constitutional values in general are confronted with a normative committment to constitutionalism and the rule of law which programmatically exists in the "older" member states.

So long as "European solutions" are felt as being imposed and detrimental to local self-interests, "modernity" (i.e. efficiency considerations and pragmatism in decision-making, irrespective of traditional values and communitarian sentiments) will be detested. However it could be that those national institutions beyond national democratic control and interrelated with European institutional networks may create institutions within the traditional national(istic) states that serve democracy.

It is believed, and in many regards rightly so, that accession to the Union will push Eastern Europe towards the values and institutional settings of modernity. Modernity, in allowing for interest group collective action, can be considered a mixed blessing. Interest group politics behind European centralization is neither particularly conducive to a robust republican design of democracy nor does it contribute to fairness with regards to the protection of minority and other vulnerable groups. ${ }^{5}$ As a result of these shortcomings relating not only to the process but also the political, historical and cultural consequences of accession the effect of modernization might, in the short term, be limited and perhaps even quite the opposite. Furthermore, the ambiguities of the European project could reinforce pre-modern values within acceding states. The current practices of constitutional public politics are limited to electoral participation of limited relevance for the decision-making. In other words, the rational discourse that allows for intellectual formation, the acceptance of governmental decisions and a more engaging decision-making process is absent.

In this paper I will look at the present impact of "Europeanization" on public understanding of constitutional democracy and the institutional structures put in place within new member states. I will then briefly consider the foreseeable

part of the horse trading that took place at the negotiations. This is a telling, though by large not unique, example of the understanding of the binding force of contracts, both in the public and among the political elite.

5 On the new European constitutional design as a project of centralization related to special interest group interest representation where they are loosing at the national level, see Ruta, M.: The Allocation of Competencies in an International Union: A Positive Analysis, http://www/ecb/int/pub/wp/ecbwp220.pdf 
impact of the emerging European Constitution on the constitutional structures (the new checks and balances) of new member states. Due to the scope of this chapter, I will not address the human rights dimension of constitutionalism. I will consider, in particular, the formation, and distortion, of constitutional democratic politics in the accession process particularly with regard to the referenda and the constitutional structures that have emerged thus far in the new member states. The politics of accession and other governmental practices remain highly instrumentalist. Such instrumentalism diminishes the likelihood that the general public will cherish the virtues of deliberative democracy and tempered majoritarianism.

Relying primarily on the Hungarian experience I will analyze the potential changes in the democratic and constitutional ethos as a result of the emerging allocation of powers in the new Union. The constitutionalist inspiration that transpires from the debate on the European Constitution as well as the draft itself is highly problematic as a blueprint for "transformative constitutionalism."

My first claim is that the accession process as well as the drafting of the European Constitution has reinforced a the irrelevance of constitutional democracy in the eyes of the public who continue to see it as a matter of majoritarianism. It remains to be seen how the emerging European Union model of pluricentric separation of powers ("network constitutionalism") will be understood and used democratically by the citizens of the new member states.

My second claim is that, outside of the genuinely free elections firmly entrenched within new member states, certain patterns of state socialism are going to be reinforced through membership to the Union. Democratic politics is understood for many people as a tool of maintaining free public services, irrespective of contribution or need (except the needs of service providers). Such trends might be reinforced whist converting local constitutional politics to the European level. The experiences of the accession process indicate that democratic participation and parliamentarism are often quite formal. Instead of genuine participatory politics and accountability, democracy becomes an opportunity to influence politics in order to maximize welfare services. Union

${ }^{6}$ Transformative constitutionalism is about openness to the future and it is based on a critical relationship to the past. In the distinction of preservative and transformative constitutions I follow Cass Sunstein, Designing Democracy. New York, Oxford University Press, 2001. 67.

On the pre-modern traditionalism of post-communist constitutions see Sajó, A.: Preferred Generations: A Paradox of Restoration Constitutions. Cardozo Law Review, 14 (1993) 847-864. 
law and policies reinforce the welfare entitlement attitudes of the East European public. The Union has its own social welfarist value system (or routine) which reinforces the inherited welfarist expectations in the new member states. In these countries the use of resources for the maintenance of European Union type welfare systems might be counterproductive and contribute to the difficulty in creating a robust democratic and constitutional culture.

\section{Constitutional structures and the thinning of majoritarian democracy}

\section{A. "Europe Clauses"-Preservative constitutionalism}

Eastern European accession countries have recent constitutions that were created after the collapse of communism. ${ }^{7}$ The Estonian Constitution (1992) (Art. 1), ${ }^{8}$ and the Czech and Slovak constitutions (1992) declare the respective countries to be sovereign, while Poland (1997), Hungary (1990 amendment), Latvia (1992), Lithuania (1992) and Slovenia (1991) refer to independence. Lithuania's Constitution also states that people's sovereignty cannot be limited. Even in cases where the Constitution is less unequivocal (as in Hungary) prevailing national sentiment is well represented in the jurisprudence of the Constitutional Court. Here a very traditional concept of sovereignty (see below) has been agreed upon which in turn has resulted in the restrictive wording of the Europe clause in Hungary. The transfer of public powers is not possible. Only the transfer of the right to exercise certain powers is allowed since such a transfer cannot be based on the ultimate source of sovereignty-the Hungarian people. ${ }^{9}$

This concern with state sovereignty as a basis for independence is remarkable when compared with Western European constitutions where the matter is either not discussed at all, or is not made explicit (see e.g. Austria, ${ }^{10}$

7 The Hungarian Constitution is technically the Constitution of 1949 but it was fully amended in 1989 with several additional revisions since then.

8 "Estonia is an independent and sovereign democratic republic wherein the supreme power of the state is held by the people." The formulation follows closely Art. 1 of the 1938 Estonian constitution which is the basis of the adoption by referendum of the 1992 constitution, as expressly stated in the Preamble of the 1992 Constitution.

${ }^{9}$ See for example Várhelyi, O.: Hungary. In: Ott, A.--Inglis, K. (eds.): Handbook on European Enlargement. The Hague, 2002. 264.

${ }^{10}$ The Austrian Constitution states (Art. 1) that her legal order originates in the people. This, of course, can be seen as a reference to sovereignty. 
Belgium), or is referred to in the context of the source of sovereignty: Italy, Art. 1.; France, Art. 3.-where sovereignty pertains to the people; Spain Art. 1.2 - where the people are the depository of sovereignty; Portugal is one of the few exceptions where there is direct reference to state sovereignty.)

Since EU membership affects sovereignty, and arguably the independence of Eastern European states, it is understandable that the independence and sovereignty clauses are therefore seen as obstacles, to integration. The importance of these provisions is increased not only because they touch upon foundational issues but also as a result of the pro-independence public sentiment. The population in nation-states with newly recognized or regained sovereignty is understandably sensitive to issues of independence. Opposition politicians are ready to bring up the issue hoping for increased popularity in a society where popular culture traditionally honors (unsuccessful) heroes of independence. Moreover, the cultural and the legal elite are often keen on emphasizing independence as a fundamental constitutional principle (because of the constitutional wording and independence dreams in the legal traditions). Both the general public sentiment and the ongoing political conflicts explain why constitutional amendments intended for accommodating the operations of the Union are sometimes rather narrow.

By way of comparison it is worthwhile noting that the various approaches of transferring competence within the Europe clauses are essentially compatible with the prevailing continental constitutional solutions that emerged in the post-Maastricht context. The East European accession countries have carefully considered the constitutional solutions adopted in the Member States after Maastricht. The EU made it a priority to provide a knowledge base of expertise in this area. Given the increasing uncertainty of the nature of the Union, its identity, mission and decision making powers at the time the accession clauses were being written into the respective constitutions, it is understandable why some accession countries were reluctant to take a final position on the transfer of powers and competencies to the Union. The Latvian amendment, for example, expressly considers the accession to be subject to revision by way of a referendum that can be initiated by the people. Lithuania's amendment of Art. 136 also contains a safeguard clause: "The Republic of Lithuania participates in international organizations if such participation does not contradict interests of the state and its independence." However, the Europe clause states that it expressly "transfers to the EU the competencies of the national institutions in the fields foreseen in the Founding Treaties of the EU, so that it shall be entitled to implement common competencies with other EU member states in those fields." 


\section{B. Referendum-Instrumentalism and lack of deliberative democracy}

Given the concern with independence and (popular) sovereignty and because of the fundamental changes that will occur as a result of accession, all the Eastern European countries concerned opted for a referendum to sanction accession (or the accession treaty). This was irrespective of whether this form of popular support is prescribed by the constitution or not as was the case of Hungary until the 2002 amendments, or Poland (where this is a matter of choice). Indeed, some of the constitutions were amended so that they include the requirement of confirmation by referendum. It would be expected that those firm believers in popular sovereignty (i.e. that sovereign power resides in the people) would welcome this position. However, with the significant exception of Lithuania, ${ }^{11}$ the Eastern European accession countries (which do constitutionally and doctrinally endorse the position of popular sovereignty) have been keen on avoiding referendum and plebiscite. For instance there was no referendum even in the case of the dissolution of Czechoslovakia. Mobilizing for a referendum has always been a problem because of the quorum difficulties. Hungary barely satisfied the fifty per cent participation requirement in the case of the Hungarian NATO accession referendum. All previous referenda ended unsuccessfully in Slovakia where the law on referendum requires (as it was the case in Hungary) that voter turn-out must be higher than 50 percent of all registered voters in order for the referendum to be valid. Also many previous attempts at holding a referendum were perceived by the Eastern European political establishment as populist attempts to undermine the parliamentary constitutional order. (For the actual destabilizing effects of the use of referenda see its use in the power struggles between the Parliament and the President of Ukraine and similarly in Moldova. ${ }^{12}$ ) It is quite telling that the Hungarian Constitutional Court, although in principle a protector of the individual political right to referendum, systematically restricted the applicability of referendum declaring various initiatives to be disguised attempts at amending the Consti-

\footnotetext{
${ }^{11}$ The Lithuanian constitution stresses the constitutional and constituent importance of referendum from its moment of creation. Art. 9.1 provides that on matters of fundamental importance affecting the population or the country referendum be held. Note that the independence of Lithuania was restored through a 1991 referendum that was the culmination of mass resistance to Soviet rule.

${ }^{12}$ For a review of the use of referenda see Dorsen, N.-Rosenfeld, M.-Sajó, A.-Baer, S.: Comparative Constitutionalism. West, 2003. ch. 3.
} 
tution. The Hungarian Constitution was amended in 1997 to the effect of curtailing the use of referendum as a device of change. ${ }^{13}$

On the one hand a theory of constituent power that denies the right of popular initiative in this context is perhaps an odd one but, on the other hand, it is quite understandable with regard to constitutional stability: a value that was considered crucial in the early formative years of the new democracies.

Notwithstanding the lack of constitutional positions, and the remarkable legitimacy of the available specific parliamentary process, ${ }^{14}$ the political elites of all East European countries sensed (without any specific discussion) that accession needs a plebiscite-like popular endorsement. In a way, a referendum is not the preferred constitution amending procedure in the case of these easyto-amend constitutions, neither is the tool of referendum intended to become the choice even after the current round of amendments. In fact, in most countries the mechanism foreseen to handle future constitutional amendments resulting from EU developments excludes the referendum (although Estonia and Latvia are somewhat ambiguous exceptions). The governments' desire of popular legitimation resulted in one-time solutions regarding referendum, yet exceptionalism in constitutional matters is always a cause for concern.

It is possible that the use of a referendum will create certain expectations with regard to future constitutional amendments and EU constitutional changes. The currently prevailing anti-referendum constitutional pattern seems, however, unchanged. Indeed, at least in Hungary (but not in the Czech Republic) the political elite finds that there is no need to accept the European Constitution via referendum because low level endorsement would be seen as a vote of non-confidence in the government; a referendum would provide additional opportunities for the parliamentary and extra-parliamentary opposition to

\footnotetext{
${ }^{13}$ The amendment was adopted by the socialist-liberal coalition ruling at the time, which disposed of a parliamentary supermajority sufficient to constitutional amendment. The provision became an obstacle in 2003 for the same coalition which currently has only a narrow majority. Because the socialist-liberal coalition restricted the use of referendum they could not and will not be able to bypass the resistance of the opposition in accession matters by calling a referendum (where they probably would have a clear majority); the special terms of the one time referendum on accession required the consent of the opposition.

${ }^{14}$ Wyrzykowski, M.: European Clause: Is it a Threat to Sovereignty? In: Wyrzykowski, M. (ed.): Constitutional Cultures [Institute of Public Affairs, Warsaw M (2000)]. at 278 indicates that a large coalition is needed for ratification. The Polish Constitution is prudent enough to enable parliamentary majority to go to the country via referendum in order to circumwent stalemate and opposition blackmail. The Hungarian socialists, when in power, ruled out that possibility through a constitutional amendment. That possibility, of course, determines the opportunistic behavior of the parliamentary opposition of the day.
} 
impose its will on the government. Such considerations are clearly pragmatic and instrumentalist. Of course, within the Union, as the 2002 Irish referendum indicates, the allowance for a referendum remains an important popular control device over executive activities. "It is clear that retained powers of the people may force government to bring about greater domestic scrutiny of EU legislative proposals in advance of the referendum." 15 Without such a device the executive will gain further powers.

\section{A new separation of powers in the Union: further loss of popular- democratic control}

The most fundamental (substantive and procedural) changes in the Eastern European constitutional systems, laws, institutions, and societies will occur in the years immediately proceeding accession. It is only at that significant moment that an entirely new institutional mechanism will redefine these relations. Most of these changes will not be reflected in the constitutions unless there will be fundamental changes in the Union itself through the emerging constitutional framework. The interpretation of the constitutions and the extraconstitutional interpretation of sub-constitutional laws and institutions in political practices will, however, reflect these changes.

The constitutions of the new member states so far poorly reflect the shifts in decision-making. The current amendments address the role of the legislative branch in the formulation of future European policies and legislation in a minimalist way, allowing in practice the increase of the power of the executive. The amendments were adopted following instrumentalist considerations and as part of ordinary party politics. The prevailing solution limits the role of national Parliaments in the shaping of European decisions to that of a consultative body. ${ }^{16}$

In fact the powers of most parliaments will diminish and in some respect the powers of the executive will further increase especially in the case of those

\footnotetext{
${ }^{15}$ Hogan, G.: European Union Law and National Constitutions: Ireland. FIDE XX Congress, London 2002) www.fide2002.org 24.

${ }^{16}$ The model of consultative status for national parliament in the EU decision-making relies on the German model. Today many observers find this to be an insufficient solution for a parliamentary representative democracy, although contrary to Hungary or the Czech Republic the German government is subject to more stringent control, given the structure of joint-decision making in certain federal areas. In other words, because of the federal structure there is more power retained by Land legislative bodies, including through the Bundesrat. Of course, the Bundesrat does not genuinely fit the model of an elected representative body, since it is composed of non-elected Land government representatives.
} 
Eastern European countries where the matter is simply pushed under the carpet. However because of the current cabinet dictatorship in most Eastern European countries the legislative branch is already weak by design. The emerging new division of powers takes away Parliament's legislative powers in matters that are of Union competence and renders unclear those legislative powers related to implementing legislation, that is if such powers will be retained by the national Parliament at all. In addition the present constitutionally provided control powers of parliament (relating to fundamental rights protection that require some form of supermajority in some East European countries) will erode. These developments will contribute to an increasing sense of loss of popular control over the nation's destiny and the irrelevance of constitutional institutions.

\section{Does the European Constitutional System provide constitutionalism for the new member states? ${ }^{17}$}

The lack of transparent popular representation may not be the ideal beginning for the people of the new member states about to set foot on a common European path that is leading to a partially uncharted European decision making process without full representation (or with a new complex representative system based on partial representation). The representative element of the concept of the representative government is at stake. It is unlikely that people will be compensated for this loss of representative democracy by direct elections to the European Parliament. The further loss of importance of the national parliaments fits into an existing European trend. Weiler refers to a "flexible" Europe with a "core" "at its center" that "will actually enable that core to retain the present governance system dominated by the Council-the executive branch of the Member States-at the expense of the national parliamentary democracy. Constitutionally, the statal structure would in fact enhance even further the democracy deficit." ${ }^{18}$ (Emphasis added.) The national legislative branches are the losers. Given the current constitutional arrangements, namely the lack of competence and information in national Parliaments as well as parliamentarians' defective capacity to handle the issues that are to be determined by the Council, Parliaments will not be able to defend the subsidiarity principle even if there were national or Union powers to that regard in the future. On the other

\footnotetext{
${ }^{17} \mathrm{I}$ am not considering here the rule of law and human rights enhancing contribution of the Union to the new member states-here the advantages are more obvious.

${ }^{18}$ Weiler, J. H. H.: Conclusions. note 4. (Conference paper) Europe 2004-Le Grand Débat: Setting the Agenda and Outlining the Options. Brussels, 15 and 16 October 2001.
} 
hand the national executive will be in the position to push through policies in the Council that it would not be able to push through its own Parliament because opposing public opinion, or majority (or coalition) party interests, or supermajority requirements would present insurmountable obstacles. ${ }^{19}$

On the basis that alternative forms of democracy are rather weak in East European civil societies, the European "democracy deficit" will be reproduced (in different forms) locally. However, this negative consequence might be countered by other consequences of membership. Furthermore given that European integration "has been, historically, one of the principal means with which to consolidate democracy within and among several of the Member States, both old and new, with less than perfect historical democratic credentials, ${ }^{20}$ accession may well have a beneficial overall effect on the quality and strength of the kind of democracy, or at least rule of law and political civility, practiced in the countries to join.

The transfer of powers from national Parliaments to the Council reshapes the fundamental relations among the branches of power in the respective member states without any public participation or even any public cognition of the new development. One may argue that in the parliamentary systems that prevail in Eastern Europe the separation of powers does not offer much protection against abuse of power anyway. Parliamentary systems per se are weak substitutions of the working model of a robust democracy based on long standing traditions. Therefore there is not much to lose in the Europeanization process. However, the constitutional performance of the new states was surprisingly good in the last decade. Even if parliamentary representation and traditional checks and balances are weakened, there are other sources of legitimacy such as government efficiency. The above concerns are motivated by abstract principles of the theory of democratic representation. To use normative claims is perhaps somewhat misguided in this case. After all, the existing parliaments have never had a decisive influence on the executive but have merely served as transmission belts that convey the results of popular elections through the mechanism of the formation of the cabinet.

It can certainly be said that from a constitutionalist perspective, and contrary to a democratic theory perspective, the new "allocation of powers" is not objectionable per se. In fact the likelihood of power concentration within a single hand is further diminished. The arrangement, however, does not automatically

${ }^{19}$ Consider, among others Pernice, I.: Der Parlamentarische Subsidiaritätsausschuss. Walter Hallstein-Institut WHI-Paper 11/02. Berlin, September 2002), www.whi-berlin. de/pernice-psa.htm.

${ }^{20}$ Weiler: above n. 18, 220. 
increase the power of the people via improved self-determination. Given these preconditions and because of the fact that the accession constitutional amendments did not arise as a consequence of a crisis, one should not expect more robust national Parliaments debating European issues. The trends that emerged in the Nation State (the domination of the executive in the welfare administrative state) are not challenged through the process but were able to determine the constitutional regime of accession. A Constitutional safeguard of efficient governmental information to Parliaments and people regarding pending EU decisions, or lack thereof, makes no difference here.

The consequences of the constitutionalisation of accession do not necessarily enhance constitutionalism. The whole process is marked by ad hockery and most steps taking the new member states into the Union remain within the ordinary and quite open horse trading between opposition and majority. The political elites of Eastern Europe opted for an accession referendum. This looks like a gamble: the issue is not popular deliberation but demonstration of loyalty via plebiscite. The legal discussion is primarily about expediency of the procedure (see Slovenia), and political discourse is replaced by guesswork about quorum and majorities. This is hardly an example of taking people seriously.

At first glance it seems that national parliamentarism, the quintessential form of democratic government in the public imagery and a bulwark against executive tyranny, is going down the drain. However, this is not necessarily the message coming from the European Union. In view of the EU Treaty Parliaments remain important:

- in exercising political scrutiny of the positions adopted by their respective governments within the Council;

- in establishing cooperative relations with other parliaments in the EU;

- in drafting and implementing EU law;

In addition, the draft EU Constitution provided for additional opportunities and powers to national Parliaments. These new opportunities would have included direct and (more or less timely) notification regarding planned European legislation and opportunities of recourse, formally independent of the national executive in matters of abuse of the subsidiarity principle. One could argue, however, that these possibilities are not genuine possibilities for national parliaments as the identifiable instruments of representative government. The direct impact of national representative governments on the European Parliament (through national delegates of Parliaments who might have binding mandate) disappeared with the system of direct elections. The proposal to create a second chamber representing national Parliament has never been popular. It is true that 
there is a certain sentiment that national Parliaments deserve special attention in the European legislative process for reasons of democratic representation, "being close to citizens" 21 rather than for reasons of national sovereignty. But the prevailing understanding is that powers in the Union emanate from the EU Constitution, even with regard to constitutionally established matters of subsidiarity.

Even with improved possibilities of early warning of Parliaments (as light of past experience, that national Parliaments will make use of these suggested in the European draft Constitution) one cannot take for granted, in the opportunities. Moreover, given the remaining opportunities of national parliamentary involvment, the position of the parliament might be that of defensor of national interests. Especially in case of the subsidiarity recourse it might be embarassing for the majority to endorse a position against the one that the executive has endorsed. On the other hand, and with particular relevance to new member states which are in the shadow of suspicion of being inculcated by nationalism, the opposition of the day might be inclined to castigate the majority and the government for giving up the national interest by not taking a clear position against a Commission position or a piece of European legislation that might be challenged on subsidiarity grounds. In this scenario national Parliaments may become the forum of nationalism.

Of course, the demise of national parliaments, even if it occurs, does not rule out alternative forms of parliamentarism, and more broadly, a deliberative democracy. The European Parliament offers a form of expression of popular will. How deliberative the European legislative process will be is a matter to be seen. What is more obvious is that the European parliamentarism, deliberatly and to a great extent, offers representation for the European identity of their electors, as the system allows for less effective national interest representation (in the sense of primordial national interest).

Certain features of the European Parliament might have negative impacts on the public in the new member states. For representatives coming from smaller countries there is little they can do about the nationalistic sensibilities of their electors. For small states the elected representatives will have no chance to represent successfully nationalistic interests. As they join big panEuropean factions where blocs of larger countries dominate they will be dissolved and disappear in this distant formation. It is unlikely that the activities of the Parliament will satisfy the nationalistic expectations of the public in a small country. This might increase a sense of abandonment of national interests

\footnotetext{
${ }^{21}$ See e.g. French Convention representative Haenel, H.: http://european-convention.eu. int/docs/wd4/3640.pdf
} 
and add to the feeling that there is no genuine representation at the European level.

One could argue that Senate members in the US are also popularly elected in their state constituency without losing their state-interest representation capacity. But the differences are formidable both in terms of the constituency and the way the representation is organized in the two systems. The constituency difference can be explained in reference to the planned motto of the European Constitution: representation in Europe is about unity in diversity; in the US diversity within unity that prevails. As to the constituency, the European MP represents a nationality — his electors are mostly of the same nationality, and of the same state. All US Congressmen are elected by Americans, who might have local (state or substate level) interests or ethnic affiliation. A congressman elected in a predominantly black, Jewish or Irish district (and most districts do not have such profile) will represent Americans first, with some ethnic positions on a few issues. This is not the case in Europe where the districts create clearly national constituencies, however, the representatives are forced to abandon this implicit mandate where it is dictated by (party) ideology, by European party discipline, and, most of all, by sheer numbers.

The logic of European legislation satisfies certain conditions of deliberative democracy, not necessarily because of the dialogue within the Parliament but because of the inter-institutional dialogue. Unfortunately this discussion is likely to remain non-transparent. Furthermore one cannot take for granted that the system has the potential to remedy the problem of bureaucratic-administrative homogeneity that characterizes executive legislation ${ }^{22}$ and that is a major problem at the national level in regard to the implementation of European law (directives being implemented bypassing the legislation, via executive regulation). The problem of administrative homogeneity ("like-mindedness") remains where the interaction is between central (European) administrators and likeminded national administrators. (These latter are "like-minded" because of a proEuropean training.) And even where there is interaction with the elected European or even national Parliaments these might share the administrative European ethos too. (See the impact on legislation and robust democracy of the composition of the legislature in Germany where civil servants are elected to Parliament in great numbers.)

\footnotetext{
${ }^{22}$ Executive legislation in the administrative state runs the risk "of a situation in which like-minded people are pressing one another toward an unjustifiable position." Sunstein, C. R.: Designing Democracy. What Constitutions Do. New York, Oxford University Press 2001. 141. Sunstein argues that control of delegated legislation is a remedy.
} 
The nature of European Union law further diminishes the positive impact of the inter-institutional dialogue as fundamental problems are left unsettled, either because of subsidiarity or due to unprincipled political, intergovernmental, or inter-institutional compromises that leave matters unresolved or for decision-making at the national level, which often means exclusively executive legislation, to the detriment of public deliberation. The politically uncotrolled executive regulation means that the implementing regulation is prepared and enacted within the civil service. It is here that the insufficient constitutional/rule of law experience and the interest in democratic control will impose a high cost on the new member states. It is likely that in these countries there will be no public or institutional insistance that regulatory matters, other than dealing directly with fundamental constitutional rights restriction, be regulated in parliamentary processes. At least the Hungarian draft law on the legislative process prepared by the Ministry of Justice in 2003 intends to further restrict the domain of parliamentary law, enabling the executive to write the implenting legislation. One can already foresee the nature and qualities of regulations written by overwhelmed bureaucrats whose main concern is to have the norm pushed through without conflicts, and irrespective of constitutional, rule of law, or efficiency considerations. Of course, there are important reasons for this avoidance of Parliament: namely the dangers of delay and overpoliticization. But given the lack of commitment in the public bureacracy to constitutional/rule of law values it is at this deeper level that the fears regarding insufficient commitment to the rule of law seem appropriate. The political elite is not ready (yet?) to reshape the procedure allowing for more costly, rule of law commited procedures, partly because the same elite has an instrumental attitude to law: it is satisfied with the semblance of due process etc. This is a political elite that looks at politics as a matter of interest based horse trading, where principled positions are laughed at.

Note further that the East European civil service is not responsive to the public. Its leaders are not elected and for good reasons. Such arrangements contribute to diminished democratic accountability. Such trends might be reinforced in the environment of the European administrative state. The European administrative state has to work as an impartial entity (with regard to national interests). A democratically elected executive that controls the administrative structures would politicize the whole Union. The legitimacy of the civil service is unrelated to the democratic legitimation of the leaders, both at the European and member state level. The contrast is clear with the United States. ${ }^{23}$ National

\footnotetext{
${ }^{23}$ The prevailing US doctrine that allows administrative discretion is formulated in Chevron USA v. Natural Resources Defense Council 467 U.S. 837 (1984). Agencies are
} 
courts have no power to review the implementation legislation as it is a matter of community law.

Notwithstanding the above, the long term perspectives are not hopeless for constitutionalism in the new member states. After all, the emerging supranational separation of powers adds to that what remains of separation of powers at the national level. With regard to restricting the chances of elected dictatorship the changes are favourable to constitutionalism. It will take time to learn to live with, use and perhaps appreciate the new constitutional arrangement where the traditional branches of power operate within (and complement) networks of interest representations which have limited democratic legitimation and partial representativity. It is possible that these alternative interest representations will operate as new checks and balances: it certainly does not satisfy traditional expectations of democracy and popular representation but may perhaps provide counterbalances and at the same time contribute to a more efficient steering of the European administrative state. To the extent the Union is indeed an administrative state (with an overloaded bureaucracy composed of generalists) it does not presuppose much democratic control through national parliaments, and even through a Union level parliament.

\section{Welfarism and the perpetuation of the state-socialist endowment effect}

Given that citizens of the new member states have limited political and practical opportunities as well as material and intellectual means to determine their own fate, and that this limitation is neither disguised nor regretted in prevailing Eastern European political cultures, the traditional patterns of a welfare dependent, anti-modernist complaint-subject might be reinforced. By "complaintsubject" I mean citizens who behave like subjects of a paternalist state, who refuse to take responsibility for their fate through democratic participation, and whose "voice" (Hirschman) remains limited to complaints. People complain about their personal bad luck and the bad luck of their national history, and about mistreatment by insensitive politicians, and lack of honesty and decency of other people, in particular of those who appear to be successful. Political attitudes and action of the East European citizen remain one of complaint (hence the pattern of protest vote). The complaints include dissatisfaction with

authorized to interpret ambiguous legislative terms as they think it fit, as long as the interpretation is reasonable. Courts are expected to defer to the administrative interpretation of statutes. However, contrary to Europe, the American executive is popularly legitimated. The European and member state bureaucracies are without any popular legitimation. 
welfare provisions. It should be noted that welfarism is particularly present in Hungary with a 54 per cent rate of welfarist redistribution (that is 54 per cent of the GNP). Similar problems and welfarist-populist resistance to or reluctance to reduce welfare spending on the middle class is present in the Czech Republic and Poland. These three largest accession countries face considerable budget deficits.

As mentioned above, popular democratic control in the post-communist countries will not be enhanced after accession. Moreover, and partly related to the emerging European decision-making process, the legacy of state socialism will be reinforced; namely socialist welfare dependence will be reinforced by the prevailing solidarity culture of the Union. The Union is programmed to promote welfare as the source or precondition of European homogeneity. This will have perverse effects in many new member states. The prevailing inherited attitude of the majority of the population in the new member states is that the State should provide all sorts of services for free, irrespective of individual contribution and need assessment. (Needless to say this may not correspond to the principle of social solidarity even though it may not be in conflict with the European practices that emerge in the name of social solidarity). Most political parties and governments have subscribed to this popular/populist attitude. This primitive theory of entitlements has been elevated to a theory of "subjective rights" in Hungary; that "theory" is voiced by government and opposition and sanctioned by the decisions of the Hungarian Constitutional Court. ${ }^{24}$ Social rights serve as the basis of government provided services, which are taken for granted for all citizens. The attitude is inherited from socialism-the state socialist system provided all sorts of services in exchange for political loyalty and to a great extent irrespective of merit and economic inefficiency consequences. The resulting inefficiencies made the state socialist system unsustainable. However, the welfare expectations continued to operate in conformity with what one could expect on the basis of the endowment effect. People are generally inclined to ask much more for selling a good they possess than they are ready to pay, if asked to buy it. People estimate very highly the services which were already provided, although they would be reluctant to pay for such services. Such attitude is generally quite irrational, especially where it

\footnotetext{
${ }^{24}$ Likewise the Polish Tribunal, in the Pension cases. For Hungary, see Sajó, A.: How the Rule of Law Killed Welfare Reform, East European Constitutional Review, 5 (1996) $31-41$.
} 
helps to maintain very inefficient and costly bureaucracies, as it is the case in the post-communist countries (see, in particular the healthcare system). ${ }^{25}$

Endowed welfarism has proven to be quite popular. This popularity is not limited to Eastern Europe although richer countries may afford it more. It is a typical middle class attitude that favors, among others, the maintenance of universal services. The attitude was masterfully summarized in a dissenting opinion of Justice Kilényi of the Hungarian Constitutional Court. ${ }^{26}$ Justice Kilényi argued that social rights are to be understood in conjunction with the constitutional right to social security. Social security is far more than the right to a social existence minimum (i.e. subsistence support). It is a constitutional right that pertains to all (individuals and families), "irrespective of differences in wealth". It includes the obligation of the state not to interfere with the material conditions of the citizens in a way that imposes on the masses of citizens burdens that are disproportionate and exceed their possibilities. At the beginning of 1995 the Hungarian Constitutional Court repeatedly protected existing, noncontribution based social services as statutory entitlements amounting to acquired rights that cannot be repealed, at least not until the recipients had sufficient time and opportunity to find alternative protection. The Court and, increasingly, most political parties accepted that general entitlements, unrelated to needs assessment are "subjective rights" and pertain to all.

The social welfare dependency that is rooted in the endowment effect had dramatic fiscal consequences. Universal services that were inherited from socialism were of a nominally high quality. As a result of different populistelectoral policies, at least some of these services were further extended after the collapse of state socialism. The state could not sustain these services, or their level (quality), except at the price of excessive taxes with negative impact on investment and increasing government debt that imposed increasing fiscal burden on economic development. At the moment when the requirements of the Stability and Growth Pact became a concern to the new member states and the governments, certain governments attempted to reduce the budget deficit. There was a general public outcry against any attempt to move towards a needs assessment based welfare system. It has to be admitted that the gross income of the population is HUF $1,1 \mathrm{~m}$ (4,000 Euros) with an average of 28 per cent income tax and approximately another 11 per cent social security tax. (Only 4

\footnotetext{
${ }^{25}$ Posner argues that endowment effects are rational if the disparity reflects the unique character of the goods in question - unique in the sense of lacking close substitutes. This is certainly not the case of the welfare services which are (or would be) available on the market. Posner, R.: Economic Analysis of Law. $5^{\text {th }}$ edition, New York, 1999. 95.

${ }^{26}$ 26/1993 (IV.29.) AB hat. [annualized increase of pensions below inflation upheld].
} 
per cent of the taxpayers reported more than HUF 4,000.000 annual gross income. As long as the tax remains high (40 per cent above the 4,000 Euro bracket) there is no disposable income for social services and the population is not in the position to make informed choices, though in the given system the level of services deteriorates.

It is likely that the welfare expectations attitude will be reinforced ideologically in the Union. Further, to some extent such tendencies might be reinforced on the basis of the specific rules of the secondary legislation of the Union that reflect welfarist concerns but correspond to the possibilities of much more affluent societies. (It is a matter of conflict for the future how the new member states will satisfy the budget deficit, and national debt reduction, etc. requirements of the Euro zone.) The solidarity-inspired and other socialistic provisions of the Treaty/Constitution will enhance the attitude of middle class welfare dependence.

The European attitude was well exemplified in draft Constitution that continued to enhance the idea that a high level of health protection is to be provided under nationally determined systems as promoted by Union policies. ${ }^{27}$ To the extent that this points to an all-European standard the pressure on the weaker national economies to maintain free, or below market price services will continue. Note that the per capita health care spending in Germany exceeds at least sevenfold the Hungarian per capita expenditure, though in terms of the respective percentages of the national budgets the two countries are not fundamentally different. However, the Hungarian expenses are almost exclusively covered on the basis of a national insurance system that runs into major deficit, covered by the budget. ${ }^{28}$

I would like to illustrate the welfarist burden on the new member states (with the already mentioned consequences of welfare dependency reinforcement and negative impacts on economic development) with a more specific example that originates in the secondary legislation on commercial activities. Directive 2002/22/EC of the European Parliament and of the Council of 7

${ }^{27}$ Art. II-35: Health care.

Everyone has the right of access to preventive health care and the right to benefit from medical treatment under the conditions established by national laws and practices. A high level of human health protection shall be ensured in the definition and implementation of all Union policies and activities.

${ }^{28}$ The health care expenditure looks non-sustainable in its present system of administration based on an allegedly "acquired right". Attempts to reform the system run into the resistance of the well organized medical profession and the pharmaceutical industry, supported by the opposition of the day, claiming that any reform imposing direct costs on the population violates people's rights. 
March 2002 on universal service and users' rights relating to electronic communications networks and services (Universal Service Directive) requires that universal service be made available at "affordable price" (Article 3. 2.). Annex IV specifies that such duty implies averaged prices or the provision of specific tariff options for consumers with low incomes. The resulting loss to the operator has to be recovered from contributions from the other undertakings (who will charge more to their users). I am sure that even Adam Smith would offer some arguments for such arrangements referring to public goods; modern economists would talk about positive network externalities. Further, solidarity might provide additional justification for such arrangements. For example emergency calls will be available to all. However, what are the implications of such logic where large numbers of the population are of low incomes? That the affected companies (sectors) will lose their competitivity.

Welfarist provisions in European Union law, similar to the above mentioned examples are of considerable importance for reinforcing socialist mentalities of endowment and post-socialist welfare institutions with all the inherent inefficiencies, unfairness (middle class bias) and non-sustainability that it entails.

After all, the quoted welfarist provisions of European Union law seem to reflect the same welfarist perspective that the national parliaments have inevitably accepted in response to democratic pressure. Such language and policies might be attributed to the self understanding of the administrative welfarist state. The Union's institutions and networks are not catering to welfarism and function to some extent as buffers against self-destructive welfarism of democracy at the national level. Nevertheless, the comprehensive language of the Union seems to mimic what would have resulted from traditional popular representative democracy. This may not be decisive where particular policies are left to independent networks without a welfare-oriented redistributive mission. It should be added quickly that all this is intended to indicate a possible trend only, a trend that at this moment is undermined by at least three facts. Firstly, the Union does not have much power of direct reallocation as this remains within the budgetary powers of national parliaments. Secondly, the transfers of the Union are certainly and perversly redistributive (see CAP). Thirdly, there are genuine efforts to recreate representative government or a network of representative governments at the Union level that might respond to (or resist) the same redistributionist democratic impulses that characterize national parliaments. 